\title{
Institutional Review Board Independent Ethics Committee Notification of Trial Termination Document
}

National Cancer Institute

\section{Source}

National Cancer Institute. Institutional Review Board Independent Ethics Committee Notification of Trial Termination Document. NCI Thesaurus. Code C115699.

Records notifying the Institutional Review Board (IRB)/Independent Ethics Committee (IEC) of the termination of a clinical trial. 